\title{
ANOMALI DESENTRALISASI ETNISITAS MEMANCING DISINTEGRASI?
}

\author{
Suhartono W. Pranoto*
}

\begin{abstract}
Abstrak
Pelaksanaan desentralisasi yang meluas memunculkan akibat-akibat yang tidak diharapkan. Munculnya gejala etnosentrisme yang menimbulkan sparatisme mengawali keraguan pusat pemerintahan untuk mengurangi kebebasan kewenangan desentralisasi seperti kerusuhan, korupsi, oligarki, politik dinasti, yang semua itu sebenarnya sudah berlangsung di pusat pemerintahan, tetapi kemudian diimitasi dan menyebar ke daerah. Kejadian ini semua membuat keraguan desentralisasi yang mereduksi secara involutif dari nasionalisme kembali ke etnosentrisme. Menguatnya etnisitas dapat memancing disintegrasi.

Selama ada komitmen kuat dari daerah-daerah lewat local wisdom yang sudah ditransformasikan ke dalam nasiosentrisme, maka regionalism dapat ditanggulangi dan nasionalisme tetap terjaga. Dengan demikian etnocharacter menjadi penyangga nation-character yang melanggengkan unity in diversity. Revitalisaswi karakter bangsa mutlak harus dilakukan. Pancasila harus diajarkan kembali karena sila-sila didalamnya mengajarkan kepada manusia baru Indonesia untuk rukun dan gotong royong dalam kebersamaan. Bhinneka Tunggal lka tetap membingkai kebersamaan.
\end{abstract}

\section{Kata kunci: anomali, desentralisasi, etnisititas, disintegrasi}

\section{Pendahuluan}

Anonim: character is key to making a nation great

Harus diakui secara jujur bahwa bangsa Indonesia sedang mengalami krisis multidimensi yang sering dikatakan bahwa krisis ini sudah merambah berbagai segi kehidupan yang bergerak multilini baik vertilal maupun horizontal . sudah lebih dari satu desenia krisis belum pulih dalam arti kehidupan masyarakat bukannya makin baik tapi dalam kondisi ststus quo. Terlepas dari masalah sebab-sebab terjadinya krisis ekonomi dunia yang nerembet ke Indonesia, maka krisis itu berdampak sangat kompleks sehingga lamban dilakukan pemulihan (recovery) karena

* Suhartono W. Pranoto adalah Guru Besar Ilmu Budaya Universitas Gadjah Mada dan Ketua Masyarakat Sejarawan Indonesia Daerah Istimewa Yogyakarta

1|Agastya Vol. 02 No. 02 JULI 2012 
ada berbagai kelemahan internal yang diderita bangsa ini sebagai akibat dari kondisi sebelumnya yang tidak sehat dank arena tusukan krisis ekonomi itu.

Mengenai krisis yang tak kunjung tuntas ini menimbulkan keprihatinan para rohaniwan dan para moralis dengan kegalauan mereka yang mengatakan bahwa bangsa ini sudah kritis penuh ibarat perjalalan sudah sampai di bibir jurang. Persoalan makin kompleks mendera bangsa ini dan maraknya perilaku negative yang berkembang di masyarakat bukan saja masyarakat bawah, tetapi juga masyarakat atas yang mestinya jadi panutan dan pusat keteladanan.

Kondisi seperti ini mau diapakan? Tentu saja lebih dahulu diurai sebab musababnya dan didiagnosa karena bangsa ini telah kehilangan banyak karakter positif yang mengarah pada perilaku negatif yang menurunkan pamor pemerintah. Karakter tidak lain adalah pegangan dalam berperilaku (positif) dalam masyarakat yang karena berbagai hal telah tereduksi. Memang untuk mendiagnosa reduksi karakter perlu dilihat beberapa persoalan besar yang menyebabkan perubahan sosial politik bangsa ini. Sehubungan dengan lemahnya karakter ini diperlukan revitalisasi atau penguatan kembali.

Orang mengatakan bahwa karakter kuat membuat bangsa besar, bahkan Bung Karno, Presiden Pertama RI selalu menekankan perlunya pembangunan karakter dan pembangunan bangsa (nation and character building). Mengapa demikian,
Karena beliau paham benar bahwa jatuh bangunnya suatu bangsa sangat tergantung dari kuat lemahnya karakter bangsa dan itulah titik nadir kekuatan suatu bangsa. Jika karakternya lemah pasti tidak akan bisa mencapai tujuan bersama, yaitu kemerdekaan bangsa dalam membebaskan diri dari penjajah. Oleh karena itu, menurut beliau harus di usahakan supaya karakter bangsa ini kuat, tentunya harus mencakup seluruh etnik atau bangsa Indonesia.

Perlu diperhatikan bahwa bangsa Indonesia terdiri dari beragam suku bangsa dan lewat proklamasi kemerdekaan secara formal etnisitas telah disatukan dalam satu nasion Indonesia. Di sini posisi etnisitas ada di bawah nasionalisme, tetapi ia menjadi dasar dan pendukung nasion dan mereka secara secara kultural mempunyai kebebasan di daerahnya masing-masing. Bagaimana memberi keleluasaan beroperasionalnya pemerintahan daerah,yaitu setelah terjadi dampak reformasi yang semula kewenangan berpusat dipusat pemerintahan kemudian didistribusikan ke daerah-daerah lewat undang-undang No.22/1999.

Secara politis kewenangan daerah mengatur pemerintahan daerahnya menjadi monopoli daerah. Namun dampak pelaksanaanya ternyata tidak sepenuhnya seperti harapan pusat. Hal ini karena adanya subyektivitas etnik itu untuk mengangkat derajat dan identitas etniknya setinggi mungkin.Dalam berbagai hal pelaksanaan desentralisasi oleh pusat dianggap kelewat. Oleh karena itu, 
pusat mempertimbangkan beberapa hal untuk "dipusatkan" kembali.

Sinyalemen dan fakta menunjukkan bahwa desentralisasi yang kuat dengan subjektivitas itu agak sulit dikontrol pusat. Malahan getolnya kekuatan etnisitas yang memiliki subjektivitas etnis dan superioritasnya memancing untuk lahirnya regionalism dan dalam arti yang lebih keras sparatisme.

Untuk mengembalikan ke lingkup Negara kesatuan diperlukan syarat spiritual yaitu karakter bangsa, karakter yang menyatakan etnis yang beragam itu ada dalam kesatuan RI. Untuk itu diperlukan pendidikan karakter bangsa guna mengisi atau member bekal generasi muda dalam melanjutkan estafet kepemimpinan bangsa.

Dalam diskusi mengenai etnisitas, pembangunan bangsa di era otonomi daerah disampaikan beberapa pertanyaan: 1. Apa hubungan etnisitas dengan desentralisasi? 2 . Benarkah kuatnya etnisitas memancing disintegrasi? 3. Seberapa jauh pendidikan penguatan karakter bangsa mampu mencegah disinte-grasi? Beberapa pertanyaan ini diharap dapat memberi kerangka jawaban atas persoalan di atas. Sekurang-kurangnya jawaban akan memberikan masukan bagi instansi terkait ataupun para pemikir kenegaraan.

\section{Krisis Multidimensi}

\section{'Great countries build on the strength of character.'}

Hal ini bukan isapan jempol dan memang benar bahwa di Negara- negara besar dan menjadi makin besar itu karena mereka membangun negaranya dengan komitmen penuh terhadap keberhasilan suatu usaha dengan kerja keras sehingga gila kerja atau maniak kerja dan menciptakan etos kerja produktif.

Betapa urgensinya karakter bangsa Inggris yang disampaikan lewat semboyan gold, glory, god. Di dalamnya mengandung karakter yang kuat tentang ketangguhannya dalam berbagai hal, yaitu dengan mengarungi lautan luas dan buas, mengumpulkan kekayaan dan memperoleh kejayaan tentu saja lewat kerja keras, penaklukan atau perang, sembari takwa kepada Tuhan.

Kalau kita bandingkan, bagaimana dengan bangsa Indonesia? Tidak usah jauh-jauh kita bisa menghubungkan apa yang tertulis dalam lambang Negara Garuda Pancasila, yaitu Bhinneka Tunggal Ika. Kalau hal ini sudah menjadi semboyan seperti orang Inggris itu tentunya tinggal kita tegas mengimplementasikan dalam membangun kesatuan bangsa atau kesatuan antaretnik, membangun kepentingan bersama. Caranya bagaimana ya seperti yang dialami sekarang ini karena surutnya pemahaman atau penguasaan karakter bangsa, maka karakter itulah yang harus direvitalisasi.

Tampak sangat aneh apabila suatu bangsa berkarakter lemah. Mirip wayang kulit tanpa gapit (cempurit) yang sebenarnya merupakan spiritual strength dan tentunya tidak lain adalah karakternya yang membangun kekuatan. Karakter itu sendiri terdiri dari berbagai karakter yang terakumulasi yang dihimpun 
menjadi karakter utama. Jujur, tegas, disipilin, rajin, merupakan bagianbagian dari karakter besar. Akan tetapi salah satu dari karakter itu pun sudah member cirri sendiri bagi suatu etnik atau nasion. Sangat bagus jika mereka itu memiliki akumulasi karakter positif. Bisa juga sebagian besar bernilai positif, tetapi terkena stigma satu karakter negatif. Benar mereka itu jujur, rajin, kerja keras, disiplin, tetapi korup. Jelas hal ini mengurangi nilai karakter secara keseluruhan. Yang diharapkan bagi bangsa atau etnik adalah akumulasi nilai karakter positif itu tadi tanpa trercela oleh stigma karakter negatif.

Krisis multidimensi harus segera diatasi lewat pendidikan karakter. Mendiknas sendiri sudah menyadari segera diperlukannya pembangunan karakter bagi generasi muda. Mereka harus diajari perilaku positif untuk bisa membedakan mana yang boleh dan tidak, mana yang halal dan mana yang haram, mana mengonsumsi mana memproduksi dan sebagainya. Pendidikan karakter sejak dini meski memerlukan waktu lama dipastikan hasilnya sangat menjanjikan. Pendidikan moral dan perilaku tentunya bukan hanya pendidikan di kelas, tetapi pendidikan di keluarga menjadi sangat penting sebab disitulah awal pendidikan karakter. Selanjutnya, sekolah menjadi tempat pendidikan karakter kedua dan masyarakat ikut mengontrolnya. Namun, semuanya itu harud diberikan konsep, konten, metode, evaluasi, dan kontrolnya sekaligus.

Krisis multidimensi sebagai dampak dari pemerintahan Orde Baru yang sentralistis masih terasa. Kekuatan pemerintah di back up oleh penerapan Pancasila sebagai azas tunggal. Pelajaran Pancasila masuk dalam kurikulum Sekolah Menengah Pertama pada 1976 melalui pelajaran Pendidikan Moral Pancasila (PMP). Tidak satu organisasi dan partai pun yang tidak mengakui keberadaan dan loyak kepada Pancasila dan fungsinya sebagai alat pemersatu dalam ranah deseminasi ideologi. Jadi, dalam era ini Pancasila dipolitisasi meski akhirnya Orba harus menelan pil pahit yang diramunya sendiri.

Itu semua bukan tanpa rekayasa. Orba masih terus melakukan, pertama desukarnoisasi dan memblejeti semua sisa-sisa kebesaran pengaruh Presiden Soekarno. Sebaliknya, Presiden Suharto tengah membangun citra dan kekuasaannya yang memonopoli segalanya. Kedua, digantikannya Pendidikan Pancasila dan Kewarganegaraan (PPKn) dengan Pendidikan Kewarganegaraan (PKn) dan ketiga ignorisasi Pancasila karena orde reformasi bereforia memenangkan kekuasaan.

Undang-undang Sistem Pendidikan Nasional No. 20/2003 memberi kelonggaran dalam pasal 37 yang seolah-olah pelajaran Pancasila bukan menjadi muatan wajib seluruh jenjang pendidikan. Mengenai ini semua bisa dibaca sebagai politisasi Pancasila. Siapa perekayasa yang ada di belakangnya yang dengan pelan dan pasti berusaha menghilangkan Pancasila sebagai dasar Negara yang bermuatan karakter bangsa. 


\section{Dari Etnik menjadi Nasion}

Dari etnik menjadi nasion adalah perjuangan antaretnik itu dan berharap agar dapat meraih cita-cita bersama. Pemerintahan reformasi mendambakan harapan masyarakat tentang kebersamaan di semua bidang. Virus demokrasi sudah mewabah di Indonesia, sehingga semua unsur kehidupan di sesuaikan dengan euphoria demokrasi. Akan tetapi sering pula gamang terhadap pelaksanaan demokrasi itu,sangat sering bisa kelewatan sehingga tidak terkendali dan sangat mendambakan demokrasi. Akibatnya perilakunya berlebihan yang memarakkan kerusuhan, destruksi, tindakan anarki, dan lain-lain. Sampai-sampai saking " hati-hatinya" pada demokrasi, pemerintah tidak berani menindak hal-hal yang sebenarnya sudah masuk dalam melanggar ketertiban (orde). Prinsip demokrasi dimanfaatkan untuk kepentingan politik, golongan, dan juga pribadi.

Prinsip-prinsip demokrasi meliputi liberti, ekualiti, uniti, personalit, dan achievement. Apa yang terjadi di Indonenesia dikejar perolehannya adalah liberti dan ekualiti, sedangkan uniti mulai diutik- utik, personaliti dan achievement dilupakan alias belum sampai. Jika dievaluasi maka prinsip demokrasi di Indonesia hanya dikejar yang sesuai dengan self interestnya saja, sedangkan general responsibility belum diisi. Sebagai nasion masih melupakan konten yang harus diisinya berupa prinsip kebersamaan dalam nasionalisme. Nasionalisme sebenarnya pada awalnya juga karakter etnik yang sudah diakumulasikan yang pada masa Bung Karno difokuskan pada perjuangan melawan kolonialisme dan imperialism. Pada masa Pak Harto dipusatkan pada pembangunan, dan masa reformasi ditekankan pada demokrasi. Namun, disisi lain bahwa karakter nasionalisme pasca pemerintahan itu semua ada kandungan yang mencakup public property, sense of belonging, sense of maintaining, sense of educating, dan sense of controlling.

Namun, butir-butir di atas harus dilakukan bersama-sama oleh semua etnik atau seluruh nasion Indonesia. Proses penyadaran transetnik berlangsung terlalu mudah, tetapi harus tanpa ada rasa cemburu dan muncul superioritas etnik satu dengan yang lain. Toleransi antaretnik sangat diperlukan meski sekarang menjadi muncul toleransi berkedok ideology demokrasi. Kuatnya pembingkai kepentingan sendiri mendorong terjadinya perilaku anti toleransi terhadap etnik atau kelompok social lain. Yang pasti bahwa mendukung kebinekaan harus berhadapan dengan kelompok intoleransi itu. Jadi prinsip kebersamaan berdasar kesadaran bersama berjalan tertatih-tatih dalam pembangunan bangsa.

Hal-hal seperti itu terjadi di daerah-daerah karena menguatnya ideology demokrasi sehingga mereka tidak dapat dikendalikan,berperilaku menyimpang dan tidak sejalan dengan kebersamaan. Dari cita-cita awal sebenarnya mereka sudah kehilangan karakter karena mereka melampaui batas ekualitas antar etnik 
dan saling menghargai serta memahami.

Kondisi seperti ini kemudian terjadi turning point dan nasion sentrisme menjadi etnosentrisme. Tampak sekali diera desentralisasi ini yang nota bene sejalan dengan citacita etnik sentrisme. Primordialitas etnis makin kuat. Padahal dengan identitas,subjektifitas, Dan superioritas etnik atau daerah berpotensi untuk menolak keberagaman. Ingat bahwa kondisi Geografis Indonesia sangat rentan terjadinya separatisme dan regionalisme. Lebih-lebih jika etnis itu mempunyai sumber daya yang memungkinkan mampu berdiri sendiri sebagai pemerintahan tersendiri maka gerakan silent creeping movement dipastikan bakal terjadi di daerah.

Jadi, sebenarnya menurunya nasionalisme mau tidak mau berlangsung setelah dibukanya kran desentralisasi dan terjadilah pergeseran lokus politik. Yang semula karakter kesatuan telah tereduksi ke dalam karakter etnis atau daerah. Deangan sendirinya karakter kebinekaan telah bergeser kedaerah.dalam hal ini seberapa jauh hubungan pusat dengan daerah masih berlangsung harmonis dan control pusat atas daerah dan distribusi dan pendapatan yang proposional itu selalu menjadi tanda tanya besar.

Berbarengan Dengan otonomi daerah yang disertai dengan munculnya etnosentrisme terjadi pelunturan terhadap Pancasila. Kalau secara formal implementasi terhadapnya dihilangkan, maka akibatnya implementasinya pun juga sirna di masyarakat. Akibatnya masyarkaat tidak mempunyai pegangan. Padahal Pancasila yang menjadi dasar ideologi Negara itu pancaran nasionalisme Indonesia. Itulah sebabnya sekarang ini sedang ramai-ramainya dibicarakan kembalinya posisi Pancasila menjadi dasar kehidupan bangsa. Sudah terlanjur basah, demikian kata orang karena bangsa ini tidak sensitif dan preventif terhadap persoalan remeh yang berakibat pada pembiaran. Setelah kecurian baru mulai digalakkan ronda. Aneh bangsa ini.

\section{Kelonggaran Etnisitas}

Makin menguatnya demokrasi sebagai ideology menafikan semua perilaku bersumber pada kekebasan. Di sini etnik diberi kelonggaran sejalan dengan desentralisasi sehingga memunculkan ethnic pride. Kebanggaan etnik dibarengi perasaan superioritas terhadap etnik lain. Perasaan dan kebanggaan inilah yang mendorong kepantasan untuk berdiri di luar kekuasaan yang ada. Memang dengan segala cara mereka melakukannya tanpa sepengetahuan pusat pemerintahan. Masyarakat setempat terprovokasi bahwa etniknya bukan kelas kambing tetapi etnik pilihan. Bisa juga diambel-embeli kejayaan masa lampau bahwa etniknya pernah mengalami kejayaan dan dalam sejarahnya menyelenggarakan pemerintahan yang tertib, teratur, dan sejahtera. Model primordialitas dan nativistis ini dipakai memacu masyarakat setempat untuk memperkuat paham etnisitasnya. Bahkan karena i dendam sejarahpun dipakai sebagai 
alas an untuk bersaing dengan etnik lain dan etniknya sendiri yang dipujanya dengan menihilkan etnik lain. Persaingan tidak sehat antaretnik masih terjadi dan hal-hal inilah yang semestinya dijauhkan sebab kalau hal ini berlangsung dendam sejarah pasti akan menggelayuti republik kesatuan.

Tampak sekali bahwa setiap etnik berlomba tentang keunggulan dan kehebatannya masing-masing. Padahal semestinya arogansi direm dan saling menghormati, memahami, dan saling membantu itulah yang menjadi pilar-pilar etnisitas, bukan malahan sebaliknya. Akan tetapi sejalan dengan perubahan zaman masalah etnisitas seperti mendapat angin baru sejak otonomi daerah diberlakukan. Perlombaan antaretnis menjadikan etnis makin tinggi konfidensinya untuk dari sedikit menjalankan pemerintahan sendiri. Desentralisasi seperti yang disebut di atas mendorong muncul dan maraknya ideologi disintegrasi. Lebih-lebih daerah-dearah yang merasa mempunyai sumber daya alam lebih dan sumber daya manusia yang dianggap proporsional, mereka dari sedikit mencoba untuk itu. Ataupun etnik lain akan meniru-niru atau sekurangkurangnya menaruh harapan untuk bisa mandiri yang sedikit banyak akan memunculkan messianic move-ment.

\footnotetext{
Desentralisasi menjadi pengendali regiosentrisme dan bisa mengarah separatisme. Semakin kuat desentralisasinya dan semakin tangguh elit lokalnya, semakin kuat pula mengarah pada gerakan maker. Atau sekurang-kurangnya makin banyak
}

etnik lain yang menuntut pemekaran wilayah untuk membentuk provinsi baru. Ekor dari pembentukan itu ada semacam ethnic envy seperti disinggung di atas. Bahkan cemburu bukan saja sesama etnik, tetapi juga dengan nasion sekalipun. Ekornya adalah kerusuhan seperti yang terjadi di Provinsi Sumatera Utara tahun lalu. Untuk sementara program pemekaran daerah ditutup.

Kelonggaran etnik berdampak negatif dalam arti terjadinya rebutan etnik dan dalam lingkup mikro menjadi bangsa rebutan. Memang bangsa ini pandai berebut, tetapi kurang pandai membangun kebersamaan dan keharmonisan. Etnisitas yang dilonggarkan menjadi sebab perilaku menyimpang.

\section{Revitalisasi Karakter}

Sudah dapat diduga sebelumnya apa yang akan disampaikan oleh Presiden SBY pada hari lahir Pancasila 1 Juni. Pasti pidatonya berhubungan dengan lemahnya implementasi Pancasila dan bagaimana merevitalisasinya. Kita sudah terbangun dari kealpaan selama ini karena Pancasila diredupkan perannya. Entah disengaja atau tidak ada perubahan kurikulum pembelajaran Pancasila yang semula berdiri sendiri kemudian dimasukkan dalam kewarganegaraan. Pada kurikulum kewarganegaraan, pengajaran Pancasila dari sedikit mulai berkurang atau malahan boleh dikatakan hilang. Dari siswa sampai mahasiswa selama kurun waktu ini mulai dijauhkan dari Pancasila dan fungsinya dalam masyarakat. Sebagai pedoman peri- 
laku siswa tidak mencontoh perilaku yang berkarakter positif artinya nihil keteladanan. Para elit teras telah melanggar nilai-nilai Pancasila. Sepertinya sudah tidak ada lagi yang ada identitas dan karakter bangsa. Hak-hak rakyat sebagai warga Negara sudah dilanggar tanpa memperhatikan sila-sila dalam Pancasila. Sudah pasti mereka menjadi disorientasi bukannya Pancasila minded, tetapi kesempatan ini bisa dimasuki ideologi lain yang sengaja atau tidak ingin Mengaburkan atau malah mengganti Pancasila.

Untung pemerintah diingatkan oleh Ketua MPR dan sadar bahwa Pancasila telah tereduksi implementasinya dan karena dampaknya tidak diharapkan bagi Kesatuan bangsa, maka pemerintah timbul niatnya untuk merevitalisasinya. Selama ini pemerintah terlena karena tidak mematok Pancasila dalam blue print yang merupakan grand design artinya Pancasila tidak bisa ditawar lagi keberadaanya sebagai ideologi Negara. Meski belum terlambat benar, tetapi bangsa ini sudah terlanjur babak belur dengan radikalisme, anarkisme dan ideology NII yang lambat laun mengarah pada penggantian Pancasila. Namun, meminjam istilah Prof Syafei Ma'arif yang saya balik bahwa bangsa ini sudah siuman dari kaburisasi Pancasila. Bangsa ini kembali menata diri untuk merevitalisasi Pancasila.

Pancasila bukan properti etnik tetapi nasion. Jadi, ada pengakuan bersama manfaat Pancasila guna membentengi etnosentrisme, regionalism, dan sparatisme. Memang kalau bangsa ini ingin selamat dalam kehidupan abadi, maka tentu kita tidak ingin atau mengharapkan the end of nationality. Kalau hal ini terjadi berarti Negara kesatuan dalam kondisi wassalam.

Kita seharusnya mengimitasi model Negara maju yang konsisten dengan kokohnya karakter bangsa. Meniru yang positif adalah terpuji. Misalnya meniru bagaimana etos bushido bangsa Jepang yang menjadi Negara maju kelas dunia itu kita tiru. Etos itu muncul dari local wisdom yang diangkat menjadi karakter bangsa dan kemudian diimplementasikan dalam masyarakat. Etos kesatria yang mempunyai nilai-nilai positif dilestarikan dan dijadikan karakter bangsa. Dari hikayat, cerita, dan sejarah lokal setiap etnik di Indonesia dipastikan mempunyai karakter positif yang tetap menyejarah.

\section{Generasi Muda dan Karakter Bangsa}

Sampai sekarang belum jelas kelompok sosial mana yang harus diprioritaskan mendapat penguatan karakter. Saya berpendapat bahwa sosialisasi karakter bangsa dilakukan lewat pendidikan. Pendidikan menjadi sangat efektif karena langsung memberi warning terhadap perilaku generasi baru di keluarga. Di situ diajarkan what may and what may not. Hal-hal tabu dan permisif dilakukan dan diajarkan langsung di rumah dan ini adalah pendidikan moral dan perilaku dini. Oleh karena itu pendidikan anak di keluarga sangat penting dan menjiwai karakter 
yang menjadi bekal yang dibawanya sampai berkarir.

Tentu saja bukan hanya memberi warning, tetapi orang tua harus member contoh teladan perilaku bersih. Sebab orang tualah yang menjadi panutan anak-anaknya. Jangan ada dusta diantara orang tua, di rumah sebagai pendidikan yang saleh tetapi di luar rumah sebagai penjahat. Perilaku positif yang konsisten menjadi dambaan keluarga.

Setelah menginjak dewasa, maka kelompok sosial inilah yang dibidik untuk menerima pendidikan karakter yang lebih mantap. Mengapa demikian karena generasi muda adalah generasi penerus yang akan melanjutkan estafet kepemimpinan bangsa. Jadi, mereka harus dibekali lebih dulu supaya karakter dan moral mereka terisi sesuai dengan harapan bangsa. Vakum dan lemahnya ideologi bisa dirasuki ideologi lain dan ini sangat berbahaya. Oleh karena itu pemuda mendapat prioritas pertama dalam pendidikan karakter itu karena pemuda memiliki kesanggupan sebagai character builder (pembangun), character enable (pendaya guna), dan character engineer

(perekayasa). Faktor-faktor itu sangat diperlukan bagi kelangsungan bangsa. Bertitik tolak dari itulah tidak ada generasi muda yang 'kosong' ideologi dan tetap dibekali karakter kuat. Meluasnya generasi muda yang masuk dalam NII karena keteledoran pemerintah dalam memonitor dan melakukan tindakan tegas terhadap penyusup ideologi.

\section{Simpulan}

Pemberlakuan desentralisasi tidak lain adalah pemberian ruang dan kebebasan daerah untuk menjalankan limpahan wewenang pusat. Jadi itu adalah respon di satu sisi dan sebagai imbalan pusat di sisi lain. Namun juga sebenarnya itu semua adalah akibat produk sentralisasi kekuasaan yang terlalu besar. Selanjutnya, pelaksanaan desentralisasi yang meluas muncul akibatakibat yang tidak diharapkan. Munculnya gejala etnosentrisme yang menimbulkan sparatisme mengawali keraguan pusat pemerintahan untuk mengurangi kebebasan kewenangan desentralisasi seperti kerusuhan, korupsi, oligarki, politik dinasti, yang semua itu sebenarnya sudah berlangsung di pusat pemerintahan, tetapi kemudian diimitasi dan menyebar ke daerah.

Kejadian ini semua membuat keraguan desentralisasi yang mereduksi secara involutif dari nasionalisme kembali ke etnosentrisme. Memang beralasan karena daerah memiliki sumber daya manusia dan sumber daya alam yang memungkinkan bisa beroperasi sendiri. Etnisitas dan otonomi daerah tidak dapat dipisahkan dengan berbagai atribut dan subjektivitasnya yang ada di dalamnya. Sebaliknya, lewat local wisdom karakter etnis dapat diarahkan ke karakter nasion.

Memang tidak dapat disangkal bahwa menguatnya etnisitas dapat memancing disintegrasi. Hanya perlu kesadaran bahwa ada interes rasional mana yang dipilih antara persatuan dan persatean. Mengarah disintegrasi. 
Tidak. Jawabnya selama ada komitmen kuat dari daerah-daerah lewat local wisdom yang sudah ditransformasikan ke dalam nasiosentrisme, maka regionalism dapat ditanggulangi dan nasionalisme tetap terjaga. Dengan demikian etno-character menjadi penyangga nation-character yang melanggengkan unity in diversity.

Pendidikan keluarga awal dari keseluruhan pendidikan karakter. Orang tua mengajarkan apa yang boleh dan apa yang tidak boleh serta perilaku santun. Itu semua diajarkan dari keluarga di rumah. Sekolah dan masyarakat tinggal meneruskan. Dasar-dasar karakter sudah diajarkan di keluarga dari kandungan local wisdom setiap rumah. Pendidikan tradisional selalu berpanutan pada ratu, wiku, lan rama-ibu. Dimana mereka?

Revitalisaswi karakter bangsa mutlak harus dilakukan jika tidak ingin bangsa ini menderita demam ideologi. Pancasila harus diajarkan kembali karena sila-sila didalamnya mengajarkan kepada manusia baru Indonesia untuk rukun dan gotong royong dalam kebersamaan. Bhinneka Tunggal Ika tetap membingkai kebersamaan. Jayalah Indonesia. 


\section{Daftar Pustaka}

Ashroft, Bill, Garret Griffiths and

Helen Tiffin.1995. The

Post Colonial Studies.

Reader London \& New

York: Routledge.

Bendix,R . 1979. Nation Building and

Citizenship. New York.

Elson,R.E. the Idea of Indonesia.A

history.Cambridge :Cambridge

Univerversity press,2008.

Hatta Rajasa. "Membangun Karakter Bangsa dan Kemandirian Bangsa", dalam http://www.setneg.go.id./ index 2 php?option-comconten -\&task-vie... diunduh 5 Juli 2010 pukul 12.00 .

Roeslan Abdulgani. Pancasila: Perjalanan Sebuah Ideologi .Jakarta:

Grasindo,1988.

.Nasionalisme, Reformasi dan Gotong Royong. Jakarta: Lembaga Informasi Nasional,2002.

Sarasehan Nasional 2011. "Implementasi Nilai-Nilai Pancasila Dalam

Menegakkan

Konstitusionalitas

Indonesia." Yogyakarta: UGM.

Sartono Kartodirdjo. Pembangunan Bangsa dalam Perspektif Sejarah. Yogyakarta: Gama Press,1986.

Smith, Anthony D. 2001. Nationalism and Modernism. London :Routledge.
Soekarno. Lahirnya Pancasila. Bandung: Dua-R, 1961.

Sparinga ,Daniel T. 2003. Multikulturalisme dalam Perspektif di Indonesia. Surabaya:Forum Rektor.

Suhartono W. Pranoto. 2010. "Aplikasi dan Konsistensi Pancasila:Pasang Surut.Perspektif Historis." Makalah dalam Kongres Pancasila II, Denpasar 1 Juni 2010. ."Peningkatan

Wawasan Kebangsaan :Pasang Surut."Makalah dalam Sinkronisasi dan Harmonisasi Pengolahan Arsip Nusantara dalam Rangka Mendukung Implementasi

Pembangunan Karakter Bangsa.ANRI, Jakarta 2223 juli 2010. . 2010. "Pembentukan

Karakter Bangsa dalam Proses Historis." Makalah dalam Seminar Nasional Kebudayaan

Bali.Universitas Udayana,Denpasar 17 september 2010.

Troillot, Michel-Rolph.1995. Silencing the Past and Production of History. Boston: Beacon Press. 